\title{
FAKTOR-FAKTOR YANG BERHUBUNGAN DENGAN TINGKAT STRES MAHASISWA DI ERA PEMBELAJARAN VIRTUAL MASA PANDEMI COVID 19
}

\author{
Factors Related To Stress Level Of Students Faculty Of Health, In The Era Of Virtual \\ Learning In The Pandemic Covid-19
}

\author{
Wiwik Widiyawati ${ }^{1}$, Yuni Afifah ${ }^{2}$ \\ ${ }^{1,2}$ Program Studi S1 Keperawatan dan Ners Universitas Muhammadiyah Gresik \\ Alamat Korespondensi : Prodi Keperawatan dan Ners UMG \\ Jl. Proklamasi No. 54 Gresik- Jawa Timur - Indonesia \\ E-mail : wiwikwidiyawati@umg.ac.id
}

\begin{abstract}
ABSTRAK
Perguruan tinggi meniadakan kegiatan belajar mengajar di kampus dan mengalihkannya menjadi pembelajaran jarak jauh (Virtual), Perubahan sistem pembelajaran yang terjadi akibat Covid-19 tentunya berdampak buruk pada psikologis mahasiswa salah satunya adalah stress .Tujuan penelitian ini untuk Mengetahui faktor- faktor yang berhubungan dengan tingkat stres mahasiswa fakultas kesehatan Universitas Muhammadiyah Gresik di era pembelajaran virtual masa pandemi. Penelitian obrservasional analitik dengan desain penelitian cross sectional. Populasi 349 mahasiswa, sampel 186 mahasiswa, teknik sampling simple random sampling. Variabel independen Interaksi, akses internet, ekonomi keluarga, ketetapan jadwal, pengetahuan dan kejenuhan belajar. Variable dependen tingkat stress. Analisa data menggunakan analisis bivariat uji chi square. Hasil penelitian menunjukkan ada hubungan antara interaksi $\mathrm{p}=0,002<0,05$, akses internet $\mathrm{p}=0,000<0,05$, ketetapan jadwal $\mathrm{p}=0,000<0,05$, pengetahuan $\mathrm{p}=0,000<0,05$, kejenuhan $\mathrm{p}=0,000<0,05$, dengan tingkat stress dan tidak ada hubungan antara ekomoni $\rho=0,058 .>0,05$ dengan tingkat stress. Ada hubungan interaksi, akses internet, ketetapan jadwal, pengetahuan media SPADA, kejenuhan belajar dengan tingkat stress mahasiswa dan tidak ada hubungan ekonomi keluarga dengan tingkat stress mahasiswa. Universitas dapat merancang metode-metode baru terkait pembelajaran virtual diera pandemi atau dengan mengadakan pertemuan seminggu sekali dengan kapasitas 50\% mahasiswa sehingga bisa meminimalisir kejadian stress.
\end{abstract}

Kata Kunci : tingkat stres, mahasiswa, pembelajaran virtual

\section{ABSTRACT}

Universities eliminate teaching and learning activities on campus and switch them to distance learning (Virtual), Changes in the learning system that occur due to Covid-19 certainly have a negative impact on student psychology, one of which is stress. related to the stress level of students from the health faculty of the University of Muhammadiyah Gresik in the virtual learning era during the pandemic. Analytical observational research with cross sectional research design. The population is 349 students, the sample is 186 students, the sampling technique is simple random sampling. The independent variables are Interaction, internet access, family economy, schedule determination, knowledge and learning saturation. The dependent variable of stress level. Data analysis using bivariate analysis chi square test uji. The results showed that there was a relationship between interaction $\mathrm{p}=0.002<0.05$, internet access $\mathrm{p}=0.000<0.05$, schedule determination $\mathrm{p}=0.000<0.05$, knowledge $\mathrm{p}=0.000<0.05$, saturation $\mathrm{p}=0.000<0.05$, with stress level and there is no relationship between economy $e=0.058 .>0.05$ with stress level. There is a relationship between interaction, internet access, schedule determination, SPADA media knowledge, learning saturation with student stress levels and there is no relationship between family economics and student stress levels. Universities can design new methods related to virtual learning in the pandemic era or by holding meetings once a week with a capacity of $50 \%$ of students so as to minimize stress events.

Keywords: stress level, students, virtual learning 


\section{PENDAHULUAN}

Pendidikan tinggi diseluruh dunia terkena dampak yang signifikan akibat pandemi Covid-19. Berdasarkan surat edaran Kementrian Pendidikan dan Kebudayaan (Kemendikbud) Direktorat Pendidikan Tinggi No 1 tahun 2020 tentang pencegahan penyebaran Corona Virus Disease (Covid-19), perguruan tinggi meniadakan kegiatan belajar mengajar di kampus dan mengalihkannya menjadi pembelajaran jarak jauh (Virtual).

Menurut data UNESCO (2020)UNESCO melaporkan bahwa 91,3\% pelajar di dunia melakukan pembelajaran secara virtual, sedangkan menurut Data Pendidikan Tinggi (PPDikti) 237.193 responden dari total jumlah mahasiswa di Indonesia yang mencapai 8.325.013 mahasiswa mengatakan $98 \%$ perguruan tinggi di seluruh Indonesia sudah melakukan pembelajaran virtual (Indonesia 2020)

Pembelajaran yang awalnya dilaksanakan tatap muka atau secara langsung dialihkan menjadi pembelajaran menggunakan media virtual yang hanya dapat diakses menggunakan internet sehingga membawa perubahan pada mahasiswa (Firman \& Rahayu, 2020).

Perubahan sistem pembelajaran yang terjadi akibat Covid-19 tentunya berdampak buruk pada psikologis mahasiswa, menurut Hamzah, (2020) Mahasiswa masuk dalam golongan yang mudah sekali mengalami stres akibat tuntutan akademik .
Wang, et al (2020) melakukan penelitian menggunakan skala DASS-21 kepada 1.210 mahasiswa di Kota Cina, didapatkan hasil sebesar 24,1\% stres ringan, $5,5 \%$ stres sedang dan 2,6\% stres berat. Penelitian yang dilakukan oleh Livana, (2020) di Indonesia, didapatkan hasil bahwa $57,8 \%$ mahasiswa mengalami stres akibat dari kejenuhan, 40,2\% kurang interaksi dan 37,4\% keterbatasan signal. Stress merupakan salah satu gangguan emosional yang dapat dirasakan oleh semua orang (APA, 2017). Menurut RISKESDAS (2018)didapatkan hasil bahawa jumlah gangguan emosional khususnya di Jawa Timur sebesar 6,8\% atau sebanyak 111.878 jiwa. Hal ini menunjukkan bahwa angka kejadian gangguan emosional di Jawa Timur masih sangat tinggi dan bisa meningkat pada masa pandemi Covid-19.

Stress yang di alami mahasiswa jika tidak segera ditangani dapat menimbulkan masalah psikologis yang lebih serius seperti depresi, sehingga dapat mempengaruhi hasil pembelajaran. Pemilihan strategi koping yang tepat dapat menurunkan dampak stress mahasiswa di era pembelajaran virtual (Hanifah et al. 2020)

Terdapat strategi koping untuk mengurangi stres pada mahasiswa, yaitu problem solving coping dengan menghilangkan kondisi atau situasi yang menyebabkan stres dan bertindak aktif melakukan alternative penyelesaian masalah dan emotion focused coping dimana individu berusaha untuk mengontrol emosinya agar menyesuaikan diri dengan pengaruh yang 
ditimbulkan oleh kondisi yang menyebabkan stress (Agustiningsih 2019).

Hasil wawancara pada mahasiswa di fakultas kesehatan menyatakan bahwa stress selama pembelajaran virtual disebabkan oleh kurangnya interaksi secara langsung, gangguan koneksi internet, ekonomi keluarga, ketidak tetapan jadwal perkuliahan, kurang pengetahuan dan kejenuhan belajar. Berdasarkan data dan fenomena tersebut peneliti ingin melakukan penelitian tentang"Faktor- Faktor Yang Berhubungan Dengan Tingkat Stres Mahasiswa Fakultas Kesehatan Universitas Muhammadiyah Gresik di Era Pembelajaran Virtual Masa Pandemi "

\section{METODE}

Penelitian ini menggunakan metode observasional analitik dengan menggunakan design penelitiannya Cross Sectional. Populasinya adalah seluruh mahasiswa fakultas kesehatan Universitas Muhammadiyah Gresik sebanyak 349 mahasiswa jumlah sampel 186 mahasiswa. Menggunakan teknik sampel Simple Random Sampling. Variabel independen Interaksi, akses internet, ekonomi keluarga, ketetapan jadwal, pengetahuan SPADA, kejenuhan belajar dan variabel dependen tingkat stress . Instrumen dalam penelitian ini menggunakan kuesioner PSS-10 Dianalisis menggunakan uji Chi-Square $(\mathrm{p}<0.05)$.
UMUR

Tabel 1. Distribusi Frekuensi Responden Berdasarkan Usia Mahasiswa Fakultas Kesehatan Univiersitas Muhammadiyah Gresik

\begin{tabular}{|c|c|c|}
\hline Usia & Frekuensi & Persentase \% \\
\hline 18 & 6 & $3,2 \%$ \\
\hline 19 & 27 & $14,5 \%$ \\
\hline 20 & 56 & $30,1 \%$ \\
\hline 21 & 49 & $26,3 \%$ \\
\hline 22 & 41 & $22,0 \%$ \\
\hline 23 & 7 & $3,8 \%$ \\
\hline TOTAL & 186 & $100 \%$ \\
\hline
\end{tabular}

Sumber Data : Data Primer 2021

Berdasarkan tabel 1 dapat dilihat bahwa usia mahasiswa fakultas kesehatan sebagian besar berusia 20 tahun sebanyak 56 mahasiswa $(30,1 \%)$

\section{Data Khusus}

1. Karakteristik Berdasarkan Interaksi Dengan Teman

Tabel 2 Distribusi Frekuensi Skala Interaksi Antar Teman Pada Mahasiswa Fakultas Kesehatan Universitas Muhammadiyah Gresik

\begin{tabular}{lcc}
\hline $\begin{array}{l}\text { Skala } \\
\text { Interaksi }\end{array}$ & Frekuensi & Persentase\% \\
\hline Langsung & 69 & $37,1 \%$ \\
\hline Tidak & 117 & $62,9 \%$ \\
Langsung & & \\
\hline TOTAL & $\mathbf{1 8 6}$ & $\mathbf{1 0 0 \%}$ \\
\hline
\end{tabular}

Sumber Data : Data Primer 2021

Berdasarkan tabel 2 diatas menunjukkan sebagian besar mahasiswa fakultas kesehatan Universitas Muhammadiyah gresik berinteraksi secara tidak langsung sebanyak 117 mahasiwa $(62,9 \%)$.

\section{HASIL DAN PEMBAHASAN}

\section{Data Umum}

2. Karakteristik Kelancaran Akses Internet.

Tabel 3 Distribusi Frekuensi Skala 
Kelancaran Akses Internet Mahasiswa Fakultas Kesehatan.

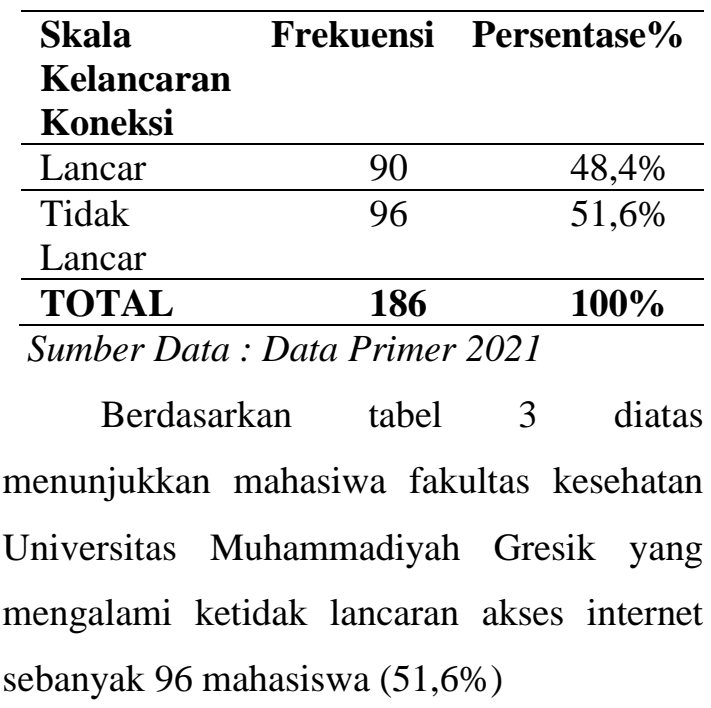

3. Karakteristik Berdasarkan Ekonomi Keluarga

Tabel 4 Distribusi Frekuensi Skala Ekonomi Keluarga Pada Mahasiswa Fakultas Kesehatan.

\begin{tabular}{lcc}
\hline $\begin{array}{l}\text { Skala } \\
\text { Ekonomi } \\
\text { Keluarga }\end{array}$ & Frekuensi & Persentase\% \\
\hline Atas & 64 & $34,6 \%$ \\
\hline Menengah & 122 & $65,6 \%$ \\
\hline TOTAL & $\mathbf{1 8 6}$ & $\mathbf{1 0 0 \%}$ \\
\hline Sut
\end{tabular}

Sumber Data : Data Primer 2021

Berdasarkan tabel 4 diatas menunjukkan sebagian besar mahasiswa fakultas kesehatan Universitas Muhammadiyah Gresik berperekonomian menengah sebanyak 122 mahasiswa $(65,6 \%)$

\section{Karakteristik Berdasarkan Ketetapan Jadwal}

Tabel 5 Distribusi Frekuensi Skala Ketetapan Jadwal Kuliah Pada Mahasiswa Fakultas Kesehatan

\begin{tabular}{lcr}
\hline $\begin{array}{l}\text { Skala } \\
\text { Ketetapan } \\
\text { Jadwal }\end{array}$ & Frekuensi & Persentase\% \\
\hline Sesuai & & \\
\hline
\end{tabular}

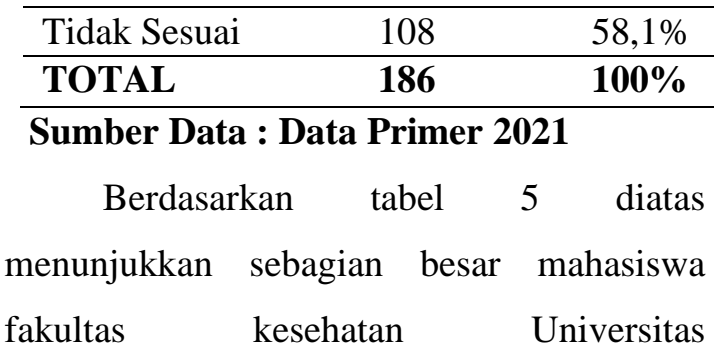

Muhammadiyah Gresik memiliki jadwal kuliah yang tidak sesuai sebesar 108 mahasiswa $(58,1 \%)$

\section{Karakteristik Berdasarkan Pengetahuan Media SPADA}

Tabel 6 Distribusi Frekuensi Skala Pengetahuan Media SPADA Pada Mahasiswa Fakultas Kesehatan

\begin{tabular}{lcc}
\hline $\begin{array}{l}\text { Skala } \\
\text { Pengetahua } \\
\text { n }\end{array}$ & $\begin{array}{l}\text { Frekuens } \\
\text { i }\end{array}$ & \multicolumn{2}{l}{$\begin{array}{l}\text { Persentase } \\
\%\end{array}$} \\
\hline Baik & 86 & $47,8 \%$ \\
\hline Kurang & 97 & $52,2 \%$ \\
\hline TOTAL & $\mathbf{1 8 6}$ & $\mathbf{1 0 0 \%}$ \\
\hline SOT
\end{tabular}

Sumber Data : Data Primer 2021

Berdasarkan tabel 6 diatas menunjukkan sebagian besar mahasiswa fakultas kesehatan Universitas Muhammadiyah Gresik memiliki pengetahuan yang kurang sebanyak 97 mahasiwa $(52,2 \%)$.

6. Karakteristik Kejenuhan Belajar

Berdasarkan

Tabel 7 Distribusi Frekuensi Skala Kejenuhan Belajar Pada Mahasiswa Fakultas Kesehatan

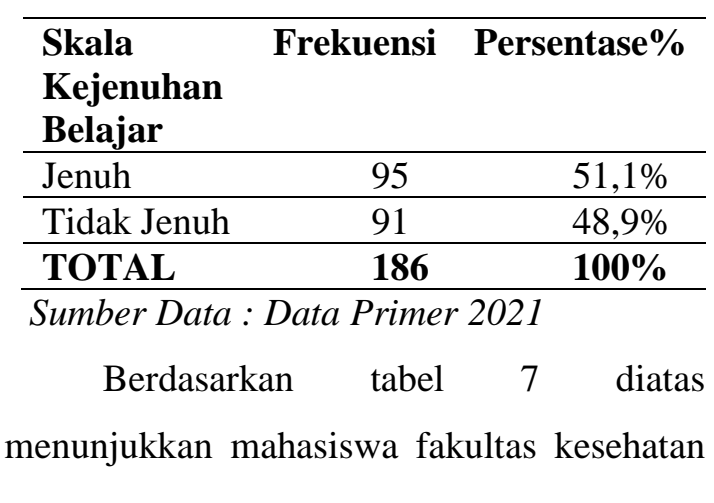


Universitas Muhammadiyah Gresik memiliki kejenuhan belajar sebanyak 95 mahasiswa $(51.1 \%)$.

\section{Karakteristik Berdasarkan Tingkat Stres}

\section{Table 8 Distribusi Frekuensi Skala Tingkat Stres Pada Mahasiswa Fakultas Kesehatan}

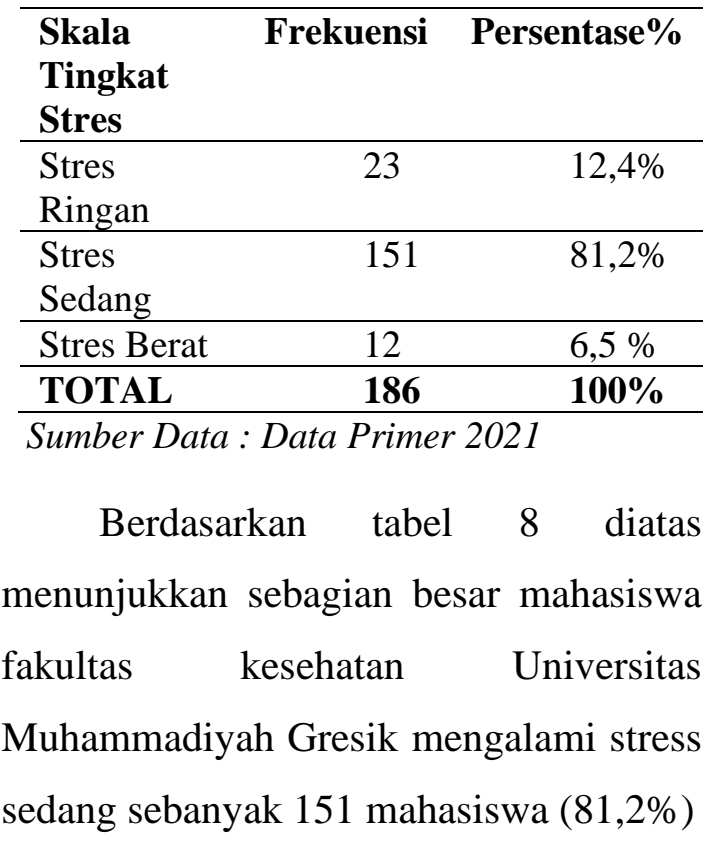

\section{Analisa Data}

Hasil dari uji Chi-Square dengan tingkat kesalahan 5\% $(0,05)$ didapatkan hasil penelitian ada hubungan antara interaksi $\mathrm{p}=0,002<0,05$, akses internet $\mathrm{p}=0,000<0,05$, ketetapan jadwal $\mathrm{p}=0,000<0,05$, pengetahuan $\mathrm{p}=0,000<0,05$, kejenuhan $\mathrm{p}=0,000<0,05$, dengan tingkat stress dan tidak ada hubungan antara ekomoni $\rho=0,058 .>0,05$.

\section{Hubungan Interaksi Dengan Tingkat Stres.} Berdasarkan hasil data pada tabel

2 menunjukkan bahwa sebagian besar interaksi dengan teman pada mahasiswa fakultas kesehatan Universitas Muhammdiyah
Gresik tergolong dalam kategori interaksi tidak langsung sebesar 177

(62,9\%). Berdasarkan Hasil dari uji ChiSquare dengan tingkat kesalahan 5\% $(0,05)$ didapatkan nilai Sig $(0,002)<\alpha(0,05)$, artinya ada hubungan antara interaksi dengan tingkat stress. Hal ini membuktikan bahwa kurangnya interaksi secara langsung maka tingkat stress yang dialami mahasiswa juga meningkat.

Manusia memiliki kebutuhan psikologis akan keterhubungan sehingga saling membutuhkan satu sama lain maka dari itu interkasi secara langsung sangat diutamakan oleh mahasiswa, Interaksi secara langsung dapat berupa diskusi kelompok ,pertemuan organisasi di tempat makan, mengerjakan tugas bersama, menyapa, dan berkunjung kerumah teman (Fatah , 2020).

Menurut Abbas (2020) pembelajaran daring untuk memutus penyebaran Covid-19 menyebabkan stres pada mahasiswa dikarekanan mereka merasa terisolasi, lelah melihat layar dan tidak ada komunikasi secara langsung dengan teman-teman.

Kebijakan Pemerintah yang mengharuskan seluruh pendidikan tinggi untuk melakukan pembelajaran virtual sehingga mahasiswa hanya perlu melakukan proses pembelajaran dirumah masing-masing tanpa perlu bertemu secara tatap muka sehingga mahasiswa akan jarang bertemu dan berinteraksi secara langsung dengan teman kampusnya, namun manusia pada dasarnya saling membutuhkan satu sama lain jika interaksi dan komikasi mereka kurang maka akan menimbulkan 
tekanan mental yang mengakibatkan stress.

\section{Hubungan Kelancaran Akses Internet Dengan Tingkat Stres}

Berdasarkan tabel 3 menunjukkan bahwa sebagian besar mahasiwa fakultas kesehatan Universitas Muhammadiyah Gresik mengalami ketidak lancaran akses internet sebanyak 96 mahasiswa $(51,6 \%)$. Berdasarkan hasil uji Chi-Square dengan tingkat kesalahan 5\% $(0,05)$ didapatkan nilai Sig $(0,000)<\alpha(0,05)$, artinya ada hubungan antara kelancaran akses internet dengan tingkat stress. Hal ini membuktikan bahwa semakin tidak lancar akses internet yang digunakan oleh mahasiswa maka tingkat stress semakin meningkat.

Ketidak lancaran Internet merupakan link disconnect atau menurunya kecepatan jaringan saat digunakan untuk mengakses yang digunakan pada media computer atau handphone sehingga tidak cukup untuk meneruskan,menerima dan mencari segala informasi yang dibutuhkan (Soepomo 2014). Menurut Fuadiah (2016) Kecepatan jaringan internet berpengaruh terhadap pencapain mahasiswa untuk megikuti proses perkuliahan, Sukarnya jaringan internet tentunya menyulitkan mahasiswa untuk mengikuti perkuliahan sehingga mengakibatkan stres yang terlalu tinggi pada mahasiswa.

Lokasi terpencil dan saat terjadinya hujan deras mengakibatkan akses internet menjadi tidak lancar bahkan jika internet digunakan secara massal dalam waktu yang bersamaan maka jaringan internet yang digunakan semakin melemah dikarenakan kinerja jaringan internet yang semakin berat .

Menurunya kelancaran internet dapat mengakibatkan suara pada media yang digunakan menjadi kurang jelas atau terputusputus, tidak dapat menampilkan gambar video ,mendwonlod file materi yang dikirim oleh dosen tidak bisa mencari tugas dan materi yang dibutuhkan untuk bahan perkuliahan, membuat mahasiswa merasa kesulitan dalam mengikuti proses pembelajaran sehingga menimbulkan stress pada mahasiswa.

\section{Hubungan Ekonomi Keluarga Dengan Tingkat Stres}

Berdasarkan tabel 4 menunjukkan sebagian besar mahasiswa fakultas kesehatan Universitas Muhammadiyah Gresik berperekonomian menengah bawah sebanyak 122 mahasiswa (65,6\%). Berdasarkan hasil uji Chi-Square dengan tingkat kesalahan 5\% $(0,05)$ didapatkan nilai $\operatorname{Sig}(0,058)>\alpha(0,05)$, artinya tidak ada hubungan antara ekonomi keluarga dengan tingkat stress. Hal ini membuktikan bahwa menurunnya ekomoni keluarga tidak menambah kejadian tingkat stress pada mahasiswa

Berbeda dengan penelitian yang dilakukan oleh Abbas ( 2020) menyatakan metode pembelajaran secara virtual memberatkan mahasiswa dari segi mental dan biaya. Hal ini disebabkan oleh kondisi keuangan keluarga yang mengalami penurunan akibat pandemi covid-19 sehingga mempengaruhi mahasiswa untuk membeli kuota internet. Mengalami kesulitan diamana ayah atau ibu mereka yang tidak mempunyai 
pekerjaan tetap atau korban PHK dari perusahaan yang terkena dampak dari covid19, sehingga pendapatan untuk memenuhi kebutuhan hidup berkurang sedangkan mereka memerlukan biaya tambahan untuk membeli kuota internet agar bisa mengikuti pembelajaran virtual, namuh saat ini pemerintah membuat kebijakan dengan memberikan kuota gratis kepada mahasiswa aktif sehingga mahasiswa tidak perlu mengeluarkan biaya untuk membeli kuota internet dan mengurangi pengeluaran keluarga.

\section{Hubungan Ketetapan jadwal Kuliah Dengan Tingkat Stres}

Berdasarkan tabel 5 menunjukkan sebagian besar mahasiswa fakultas kesehatan Universitas Muhammadiyah Gresik memiliki jadwal kuliah yang tidak sesuai sebesar 108 mahasiswa ( 58,1\%). Berdasarkan hasil uji Chi-Square dengan tingkat kesalahan 5\% $(0,05)$ didapatkan nilai Sig $(0,000)<\alpha(0,05)$, artinya ada hubungan antara ketetapan jadwal dengan tingkat stres Mahasiswa Fakultas Kesehatan Universitas Muhammadiyah Gresik di Era Pembelajaran Virtual Masa Pandemi. Hal ini membuktikan bahwa ketidak sesuaian jadwal dapat maka tingkat stress yang dialami mahasiswa juga meningkat .

Sebelum pandemi jadwal perkuliahan dilaksanakan sesuai dengan jadwal yang sudah ditentukan secara tertulis oleh pihak kampus, dalam poses belajar, mengajar penjadwalan harus disusun dengan benar sehingga tidak mengaggu aktivitas lainnya (Kartika 2020). Ketidak sesuaian jadwal yang terjadi akibat pembelajaran virtual seperti perubahan hari dan jam kuliah yang dikabarkan secara mendadak membuat mahasiswa rentan mengalami stress Kartika (2020)

Dosen pengajar yang dapat menunda dan menjadwalkan ulang perkuliahan ketika sedang berada dalam kesibukan lain dikarenakan proses mengajar belajar dapat dilakukan di mana saja dan kapan saja sehingga tidak sesuai dengan jadwal yang telah ditentukan sebelumnya hal ini yang membuat ketidak tetapan jadwal sering kali terjadi sehingga Mahasiswa merasa kesulitan dan tertekan saat melakukan proses pembelajaran yang berlangsung ketika jam bahkan hari sering kali tidak sesuai padahal mahasiswa juga mempunyai aktifitas lain yang harus dikerjakan ,ketidak susuain jadwal seringkali terjadi bahkan tanggal merah atau weekend pun mereka tetap melaksanakan perkulihan sehingga aktivitas yang sudah direncanakan jauh hari sebelumnya menjadi teganggangu mereka harus selalu stand by didepan layar laptop dan juga handphone menunggu kabar agar tidak tertinggal untuk mengikiti pembelajaran.

\section{Hubungan Pengetahuan Media SPADA Dengan Tingkat Stres}

Berdasarkan tabel 6 menunjukkan sebagian besar mahasiswa fakultas kesehatan Universitas Muhammadiyah Gresik memiliki pengetahuan yang kurang sebanyak 97 mahasiwa (52,2\%). Berdasarkan hasil uji ChiSquare dengan tingkat kesalahan 5\% $(0,05)$ didapatkan nilai $\operatorname{Sig}(0,000)<\alpha(0,05)$, artinya ada hubungan antara pengetahuan media 
SPADA dengan tingkat stress. Hal ini membuktikan semakin kurang pengetahuan maka tingkat stress pada mahasiswa semakin meningkat.

Kurangnya pengetahuan tentu ada dampaknya bagi mahasiswa dimana belum ada persiapan yang matang untuk melaksanakan perubahan yang sudah ditentukan sedangkan mahasiswa dituntut mampu menggunakan teknologi informasi yang dibutuhkan (Santaria 2020). Penelitian yang dilakukan Santaria (2020) pembelajaran virtual, tentu berdampak pada kondisi mental mahasiswa dimana belum ada persiapan yang matang untuk melaksanakan perubahan yang sudah ditentukan sedangkan mahasiswa dituntut mampu menggunakan teknologi informasi yang dibutuhkan hal inilah yang membuat mahasiswa merasakan stress.

Sosialisasi penggunaan SPADA yang diberikan oleh pihak kampus kepada mahasiswa kurang efektif dikarenakan sosialisasi dilakukan secara vitual hanya melalui media Zoom sehingga banyak mahasiwa yang kurang mengetahaui lebih jauh serta cara mengaplikasikan media pembelajaran SPADA dan menganggap bahwa SPADA justru mempersulit mereka dalam melaksanakan pembelajaran virtual sehingga mengakibatkan stress pada mahasiswa .

\section{Hubungan Kejenuhan Belajar Dengan Tingkat Stres}

Berdasarkan tabel 7 menunjukkan mahasiswa fakultas kesehatan Universitas Muhammadiyah Gresik memiliki kejenuhan belajar sebanyak 95 mahasiswa (51.1\%). Berdasarkan hasil uji Chi-Square dengan tingkat kesalahan 5\% $(0,05)$ didapatkan nilai Sig $(0,000)<\alpha(0,05)$, artinya ada hubungan antara kejenuhan belajar dengan tingkat stress. Hal ini membuktikan semakin mahasiswa merasa jenuh maka tingkat stress pada mahasiswa juga.

Kejenuhan belajar merupakan kondisi psikologi saat sesorang mengalami rasa bosan, lesu yang berlebihan sehingga memimbulkan perasaan tidak bersemangat untuk melakukan kegiatan belajar (Bildhonny 2017) penelitian yang dilakukan (Pawicara 2020) Kejenuhan belajar yang dialami oleh mahasiswa di era pembelajaran tentunya membuat mahasiswa merasa jenuh dan bosan sehingga peilaku mahasiswa menjadi lebih sensitif seperti mudah frustasi, mudah stres, cepat kesal, dan, mudah tersingung. Kejenuhan yang terjadi dikarenakan media pembelajran yang digunakan cenderung monoton dan kurang bervariasi dengan jangka waktu yang cukup lama seperti hanya melalui WA metode diskusi dan pemberian tugas membuat mahasiswa merasa kurang bersemangat Pembelajaran virtual mengakibatkan mahasiswa merasa jenuh dan kurang bersemangat dalam mengikuti proses pembelajaran sehingga mahasiswa merasa stress saat pembelajaan virtual yang dilakukan dalam jangka waktu yang berkepanjangan.

\section{PENUTUP}

\section{Kesimpulan}

Terdapat hubungan yang bermakna 
antara interaksi, akses internet, ketetapan jadwal, pengetahuan dan kejenuhan belajar dengan tingkat stress mahasiswa Fakultas Kesehatan Universitas Muhammadiyah Gresik di era pembelajaran virtual masa pandemic Covid-19

Tidak terdapat hubungan yang bermakna antara ekonomi dengan tingkat stress mahasiswa Fakultas Kesehatan Universitas Muhammadiyah Gresik di era pembelajaran virtual masa pandemi Covid-19.

\section{Saran}

Universitas dapat merancang metodemetode baru terkait pembelajaran virtual diera pandemi atau dengan mengadakan pertemuan seminggu sekali dengan kapasitas $50 \%$ mahasiswa sehingga bisa meminimalisir kejadian stress.

Hasil penelitian ini dapat dijadikan referensi dalam menentukan intervensi yang tepat bagi mahasiswa yang mengalami stress di era pembelajaran virtual.

\section{DAFTAR PUSTAKA}

Abbas, E. W., \& Erlyani, N. 2020. Menulis Di Kala Badai Covid-19.

Agustiningsih, N. 2019. "Gambaran Stress Akademik Dan Strategi Koping Pada Mahasiswa Keperawatan." Jurnal Ners Dan Kebidanan (Journal of Ners and Midwifery), (6(2),):241-50. doi: https://doi.org/10.26699/jnk.v6i2.art.p2 41-250.

APA. 2017. "Stress in America ${ }^{\mathrm{TM}}$ 2017: Technology and Social Media." Part 2. Retrieved (Stresinamerica.org).

Bildhonny, Achmad Furqon. 2017. "Menurunkan Kejenuhan Belajar Siswa Dengan Teknik Relaksasi Pada Mata
Pelajaran Pendidikan Jasmani." Seminar Nasional Pendidikan Olahraga 1(1):260-66.

Fatah Ibrahim, Eska and, Wisnu Sri Hertinjung. 2020. "Interaksi Sosial Pada Aktivis Dakwah.” Universitas Muhammadiyah Surakarta.

Firman, F., \& Rahayu, S. 2020. "Pembelajaran Online Di Tengah Pandemi Covid-19." Indonesian Journal of Educational Science (IJES) (2(2),):81-89. doi: https://doi.org/10.31605/ijes.v2i2.659.

Fuadiah, Lu'ul'ul; Hemy Heryati Anward; Neka Erlyani. 2016. "Peranan Conscientiousness Terhadap Perilaku Cyberloafing the Role of Conscientiousness Towards Cyberloafing Behavior in Students." Ecopsy.

Hamzah, B.,\&Hamzah, R. 2020. 2020. "Faktor-Faktor Yang Berhubungan Dengan Tingkat Stres Akademik Pada Mahasiswa Stikes Graha Medika." Indonesian Journal for Health Sciences (4(2)):56-67.

Hanifah, Nezha, Program Studi Psikologi, Fakultas Kedokteran, Universitas Andalas, Hany Lutfia, Program Studi Psikologi, Fakultas Kedokteran, Ulfah Ramadhia, Program Studi Psikologi, Fakultas Kedokteran, Universitas Andalas, Rozi Sastra Purna, Program Studi Psikologi, Fakultas Kedokteran, Universitas Andalas, and Universitas Andalas. 2020. "Strategi Coping Stress Saat Kuliah Daring Pada Mahasiswa Psikologi Angkatan 2019 Universitas Andalas Yang Ada Di Indonesia Untuk Melakukan Perkuliahan Jarak Jauh ( Daring ) Secara Online . Belajar Mengajar Berbasis Internet Yang Dilakukan Oleh Mahasiswa ,." 15(1):29-43.

Indonesia, C. 2020. "98 Persen Kampus PJJ Daring, Kemdikbud Klaim Mahasiswa Siap." In Cnnindonesia.Com. Retrieved (https://www.cnnindonesia.com/nasiona 1/20200903012249-20-542198/98persen-kampus-pjj-daring-kemdikbudklaim-mahasiswa-siap). 
Kartika, Rira. 2020. "MAHASISWA AKIBAT PEMBELAJARAN JARAK JAUH DI MASA PANDEMI COVID19." $1-11$.

Livana, P. H., Mubin, M. F., \& Basthomi, Y. 2020. "Learning Task Attributable to Students' Stress During the Pandemic Covid-19." Jurnal Ilmu Keperawatan Jiwa (3(2)):203-8.

Pawicara, Maharani Conilie. 2020. "ANALISIS PEMBELAJARAN DARING TERHADAP KEJENUHAN BELAJAR MAHASISWA TADRIS BIOLOGI." ALVEOLI: Jurnal Pendidikan Biologi Vol. 1(1).

(Riskesdas), Riset Kesehatan Dasar. 2018. Badan Penelitian Dan Pengembangan Kesehatan Kementerian RI Tahun 2018.

Santaria, Rustan. 2020. "Dampak Pandemi Covid-19 Terhadap Proses Pengajaran Bagi Guru Dan Siswa Pendahuluan." 3(2):289-95.

Soepomo, Prof. 2014. "IMPLEMENTASI PROXY SERVER DAN LOAD BALANCING MENGGUNAKAN METODE PER CONNECTION CLASSIFIER (PCC) BERBASIS MIKROTIK (Studi Kasus : Shmily.net)." JSTIE (Jurnal Sarjana Teknik Informatika) (E-Journal) 2(2):131-42. doi: 10.12928/jstie.v2i2.2729.

UNESCO. 2020. "290 Millions Students Out of School Due to COVID-19: UNESCO Realeases First Global Numbers and Mobilizes Response.” 5 Juli, 2020. Retrieved (https://en.unesco.org/themes/education -emergencies/coronavirus-schoolclosures).

Wang, C., R, Pan, XWan., Y, Tan., L, Xu., Cyrus, S., Ho, R., C, Ho. 2020. "Immediate Psychological Responses and Associated Factors during the Initial Stage of the 2019 Coronavirus Disease (COVID-19) Epidemic among the General Population in China." Int. J. Environ. Res. Public Health. doi: doi:10.3390/ijerph17051729. 